\title{
Design, Synthesis, Biological Evaluation and Molecular Modeling Studies of Novel Eugenol Esters as Leishmanicidal Agents
}

\author{
Camila M. Coelho, ${ }^{*, a, b}$ Thiago dos Santos, ${ }^{a}$ Poliany G. Freitas, ${ }^{b}$ Juliana B. Nunes, ${ }^{c}$ \\ Marcos J. Marques, ${ }^{c}$ Camila G. D. Padovani, ${ }^{d}$ Wagner A. S. Júdice, ${ }^{d}$ Ihosvany Camps, ${ }^{e}$ \\ Nelson J. F. da Silveira, ${ }^{b}$ Diogo T. Carvalho ${ }^{a}$ and Marcia P. Veloso ${ }^{a, b}$ \\ ${ }^{a}$ Laboratório de Pesquisa em Química Farmacêutica, Faculdade de Ciências Farmacêuticas, \\ ${ }^{b}$ Laboratório de Modelagem Molecular e Simulação Computacional, Instituto de Química and \\ ${ }^{c}$ Laboratório de Biologia Molecular de Microorganismos, Instituto de Ciências Biomédicas, \\ Universidade Federal de Alfenas, Rua Gabriel Monteiro da Silva, 700, \\ 37130-000 Alfenas-MG, Brazil \\ ${ }^{d}$ Centro Interdisciplinar de Investigação Bioquímica, Universidade de Mogi das Cruzes, \\ 08780-911 Mogi das Cruzes-SP, Brazil \\ ${ }^{e}$ Laboratório de Modelagem Computacional (LaModel), Instituto de Ciências Exatas (ICEx), \\ Universidade Federal de Alfenas, 37130-000 Alfenas-MG, Brazil
}

\begin{abstract}
Leishmaniasis is a neglected pathology with a high incidence worldwide, and is a governmental health issue due to the increased morbidity and mortality associated with the disease and a scarce therapeutic arsenal. Cysteine proteases have been investigated as targets for new drugs because they are essential in the infectivity of the parasite during its interaction with the host and in its nutrition. This study aimed to identify compounds with leishmanicidal activity, by synthesis of compounds, in vitro evaluation of their biological activity and using molecular modeling and bioinformatics tools. The study of biological activity demonstrated that one compound showed inhibitory activity against the enzyme $\mathrm{rCPB} 2.8$ at a concentration of $100 \mu \mathrm{mol} \mathrm{L}{ }^{-1}$. Activation of the enzyme rCPB 2.8 by other 4 compounds was also verified, which may be related to the interaction of these compounds with an allosteric site on the enzyme.
\end{abstract}

Keywords: eugenol esters, leishmaniasis, cysteine protease, molecular modeling

\section{Introduction}

Leishmaniasis is a disease caused by parasites of the genus Leishmania and is transmitted to humans by the bite of female phlebotomine sandflies (Diptera). It mainly affects the skin and other organs, such as the liver and spleen, often leading to skin lesions, cutaneous ulcers, mutilation, and even death, if not treated properly. The high virulence of the parasite, combined with host factors including inadequate nutritional status, age (highly elevated risk in children and elderly), immunodeficiency and some genetic factors, contribute to an unfavorable prognosis of the disease. ${ }^{1}$ Currently, infections caused by the protozoan Leishmania sp. present a growing concern due to the increase in the number of HIV-related immunocompromised patients, who are very

*e-mail: camilademoraiscoelho@gmail.com susceptible to such systemic parasitemia, mainly in Southern Europe, East Africa, Brazil and India. ${ }^{2}$ It is estimated that 700 to 1 million new cases of leishmaniasis and 20,000 to 30,000 deaths occur per year. Almost all of the global cases of visceral leishmaniasis (90\%) recorded in 2015 come from Brazil, Ethiopia, India, Somalia, Sudan and South Sudan, demonstrating the concentration of cases in the so-called developing and underdeveloped countries. ${ }^{3}$

Drugs available for the treatment of leishmaniasis are inadequate and sometimes are ineffective or expensive, with a high toxicity profile. Among them are pentavalent antimonials, pentamidine, amphotericin B, paromomycin and miltefosine. With the aim of discovering new promising drug candidates for the treatment of leishmaniasis, cysteine proteases are potential biological targets due to their importance in the infectivity of the parasite during its interaction with the host, in the invasion of macrophages by 
promastigotes form, in the evasion of the immune system, degrading components of the host's extracellular matrix, in the transformation of the vector promastigote form to the intracellular amastigote form and in their nutrition. ${ }^{4-6}$ The first compound discovered that demonstrated inhibitory activity against this enzyme, binding irreversibly to the active site on a Cys residue in a peptidomimetic manner, is the compound E-64, an epoxysuccinate obtained from Aspergillus japonicus. Similar to that occurring in peptide covalent binding, $\alpha$-ketoacids, $\alpha$-ketoesters and $\alpha$-ketoamides are electrophilic compounds that form a tetrahedral transition state when interacting with nucleophilic residues of the enzyme (Cys, Ser or Thr), but in a reversible manner. ${ }^{7}$

The active site of cysteine proteases have subsites of interaction with substrates, designated S1, S1', S2, S2' and $\mathrm{S} 3$. The $\mathrm{S} 2$ site, the major subsite, is responsible for the specificity of the enzyme and shows great affinity for hydrophobic substrates, besides allowing interaction with positively charged clusters due to the presence of a flexible amino acid glutamate (Glu205 in cruzain). ${ }^{8-10}$ The mechanism of cysteine protease catalysis is related to deprotonation of the sulfhydryl side chain group of a cysteine by the imidazole ring of the histidine, leading to the hydrolysis of peptides by the attack by the deprotonated cysteine on the substrate. ${ }^{11}$

The aims of the present study were to synthesize novel eugenol esters, evaluate their leishmanicidal activity and investigate the relationship between their biological and chemical activities using molecular modeling approaches which focus on the rCPB 2.8 enzyme. Eugenol was used as the starting material for the chemical reactions due to its affordable acquisition and knowledge of its several biological activities, including antibacterial, antioxidant and leishmanicidal. ${ }^{12-14}$ The morpholine ring is a substituent also present in a peptide-like inhibitor of a cysteine protease, the morpholino-Leu-homoPhe-FMK compound, that confers to the compounds a functional grouping of basic character. ${ }^{15}$ The possibility of interaction between the carbon of the ester carbonyl group with the Cys 25 residue of the rCPB2.8 protein, similar to the link between the enzyme and its natural substrate (peptides), was also proposed, and the influence of different electron withdrawing or electron donating substituents on the para-substituted ring was explored.

\section{Experimental}

\section{Chemistry}

Melting points of compounds $\mathbf{4 a - i}$ were obtained via a Bücher 535 apparatus. Infrared (IR) spectroscopic analysis was performed using a Thermo Fisher Scientific NicoletiS50 spectrometer. Nuclear magnetic resonance (NMR) analysis was performed on a Bruker AC-300 $\left({ }^{1} \mathrm{H}: 300 \mathrm{MHz}\right.$; ${ }^{13} \mathrm{C}$ : $75 \mathrm{MHz}$ ) spectrometer. Mass spectroscopic (MS) analysis was conducted using Shimadzu Biotech Axim Performance MALDI-TOF mass spectrometer equipment.

Synthesis of 4-allyl-2-methoxy-6-(morpholin-4-ylmethyl) phenol (2)

The synthesis of compound $\mathbf{2}$ was performed according to the method described by Abrão et al. ${ }^{16}$ The procedure was conducted in a round bottom flask containing $50 \mathrm{~mL}$ of toluene, $5 \mathrm{~mL}$ of eugenol $(32.17 \mathrm{mmol}), 5.62 \mathrm{~mL}$ of morpholine $(63.62 \mathrm{mmol})$ and $4.85 \mathrm{~mL}$ of formaldehyde ( $82.74 \mathrm{mmol})$. The reaction mixture was kept under vigorous magnetic stirring and reflux at $95^{\circ} \mathrm{C}$ for $24 \mathrm{~h}$. The reaction was monitored by thin layer chromatography (TLC; hexane/ ethyl acetate 3.5:6.5, v/v). After total consumption of the reactant, the reaction mixture underwent extraction with $1 \mathrm{~mol} \mathrm{~L}^{-1} \mathrm{HCl}$. The $\mathrm{pH}$ of the aqueous phase was raised to approximately 6 by the addition of saturated aqueous sodium bicarbonate solution and underwent extraction again with dichloromethane. The organic phase was dried over anhydrous $\mathrm{Na}_{2} \mathrm{SO}_{4}$, filtered and concentrated. Recrystallization from ethanol provided a pure sample of compound 2. White solid; yield 50\%; mp 48-50 ${ }^{\circ} \mathrm{C}$; IR (attenuated total reflectance (ATR)) $\bar{v}_{\max } / \mathrm{cm}^{-1} 3297$, 3013, 2962, 2817, 1659, 1589, 1493, 1457, 1397, 1234, 1111, 1072, 989, 906.

\section{General procedure for the synthesis of derivatives $\mathbf{3 a - h}$}

The chloride acid compounds were synthesized as previously reported by Zhang et al. ${ }^{17}$ In a round bottom flask containing $2.27 \mathrm{mmol}$ of para-substituted benzoic acid, $1.5 \mathrm{~mL}$ (20.68 mmol) of thionyl chloride was added. The reaction mixture was left under vigorous magnetic stirring and reflux at $85-90{ }^{\circ} \mathrm{C}$ for $2 \mathrm{~h}$. The reaction was monitored by TLC using a methanol mixture of the product (hexane/ethyl acetate 7:3, v/v). After $2 \mathrm{~h}$, the product was concentrated. The acid chlorides that were obtained (3a-h) were solubilized in anhydrous dichloromethane $\left(\mathrm{CH}_{2} \mathrm{Cl}_{2}\right)$ and used immediately.

\section{General procedure for the synthesis of derivatives $4 a-i$}

These esters were synthesized according to the methodology reported by Abrão et al. ${ }^{16}$ and Zhang et al. ${ }^{17}$

In a round bottom flask containing compound $\mathbf{2}$ $(0.76 \mathrm{mmol})$ and $20 \mathrm{~mL}$ of anhydrous $\mathrm{CH}_{2} \mathrm{Cl}_{2}, 2.27 \mathrm{mmol}$ 
of 4-dimethylaminopyridine (DMAP) was added, with vigorous magnetic stirring and immersion in an ice-bath. After $10 \mathrm{~min}$, the corresponding acyl chloride (3a-h) was solubilized in anhydrous $\mathrm{CH}_{2} \mathrm{Cl}_{2}$ and added dropwise to the reaction mixture at $0{ }^{\circ} \mathrm{C}$. Subsequently, the reaction was maintained under vigorous magnetic stirring and at room temperature for $24 \mathrm{~h}$.

The reaction was monitored by TLC (hexane/ethyl acetate $8: 2, \mathrm{v} / \mathrm{v})$. After completion, the reaction mixture underwent extraction with $0.5 \mathrm{~mol} \mathrm{~L}^{-1} \mathrm{NaOH}$, on crushed ice. The organic phase was extracted again with distilled water until the $\mathrm{pH}$ of the aqueous phase reached approximately 7 . The organic phase was dried with anhydrous $\mathrm{Na}_{2} \mathrm{SO}_{4}$ and filtered. The solvent was removed by vacuum evaporation and the product purified by column chromatography (CC; ethyl acetate/hexane 2:8, v/v).

\section{4-Allyl-2-methoxy-6-(morpholin-4-ylmethyl)phenyl benzoate} (4a)

From benzoyl chloride. Yellow solid; mp $84-85{ }^{\circ} \mathrm{C}$; IR (ATR) $\overline{\mathrm{V}}_{\max } / \mathrm{cm}^{-1}$ 2972, 2924, 2868, 2807, 1733, 1599, 1496, 1267, 1201, 1113, 1060, 1026, 908; ${ }^{1} \mathrm{H}$ NMR $\left(300 \mathrm{MHz}, \mathrm{CDCl}_{3}\right) \delta 8.23-8.20$ (dd, 2H, H3, H5), 7.63-7.60 (m, 1H, H1), 7.53-7.48 (m, 2H, H2, H6), 6.83-6.78 (m, 2H, H10, H12), 6.03-5.91 (m, 1H, H21, J $\mathrm{H} 21-\mathrm{H} 206.69 \mathrm{~Hz}$, $\left.J_{\mathrm{H} 21-\mathrm{H} 22 \text { cis }} 10.11 \mathrm{~Hz}, J_{\mathrm{H} 21-\mathrm{H} 22 \text { trans }} 16.91 \mathrm{~Hz}\right), 5.15-5.09(\mathrm{~m}$, 2H, H22), 3.80 (s, 3H, H14), 3.47-3.39 (m, 8H, H17, H18, $\left.\mathrm{H} 20, J_{\mathrm{H} 20-\mathrm{H} 21} 6.69 \mathrm{~Hz}\right), 2.35$ (m, 4H, H16, H19); ${ }^{13} \mathrm{C}$ NMR $\left(75 \mathrm{MHz}, \mathrm{CDCl}_{3}\right) \delta 40.14$ (C20), 53.28 (C16, C19), 55.99 (C14), 58.32 (C15), 66.54 (C17, C18), 111.96 (C12), 116.20 (C22), 122.74 (C10), 128.50 (C2, C6), 129.84 (C4, C8), 130.18 (C3, C5), 133.28 (C1), 137.08 (C21), 137.47 (C9), 138.35 (C11), 151.71 (C13), 164.40 (C7); MS matrix-assisted laser desorption/ionization-time-offlight (MALDI-TOF, $m / z$ ): calcd. for $\mathrm{C}_{22} \mathrm{H}_{25} \mathrm{NO}_{4}[\mathrm{M}-\mathrm{H}]$ : 366.17; found: 366.32 .

\section{4-Allyl-2-methoxy-6-(morpholin-4-ylmethyl)phenyl 4-nitrobenzoate (4b)}

From 4-nitrobenzoyl chloride. Yellow solid; yield 29\%; mp 112-118 ${ }^{\circ} \mathrm{C}$; IR (ATR) $\overline{\mathrm{v}}_{\max } / \mathrm{cm}^{-1} 3077,2971,2917$, 2856, 2807, 1742, 1598, 1524, 1493, 1454, 1347, 1263, 1196, 1111, 1071, 1009, 898; ${ }^{1} \mathrm{H}$ NMR (300 MHz, $\left.\mathrm{CDCl}_{3}\right)$ $\delta$ 8.41-8.33 (m, 4H, H2, H3, H5, H6), 6.80 (s, 1H, H10), 6.79 (s, 1H, H12), 6.04-5.91 (m, 1H, H21, $J_{\mathrm{H} 21-\mathrm{H} 20} 6.72 \mathrm{~Hz}$, $\left.J_{\mathrm{H} 21-\mathrm{H} 22 \text { cis }} 10.26 \mathrm{~Hz}, J_{\mathrm{H} 21-\mathrm{H} 22 \text { trans }} 16.76 \mathrm{~Hz}\right), 5.15-5.10(\mathrm{~m}, 2 \mathrm{H}$, H22), 3.81 (s, 3H, H14), 3.41-3.39 (m, 8H, H15, H17, H18, $\left.\mathrm{H} 20, J_{\mathrm{H} 20-\mathrm{H} 21} 6.69 \mathrm{~Hz}\right), 2.28$ (m, 4H, H16, H19); ${ }^{13} \mathrm{C}$ NMR $\left(75 \mathrm{MHz}, \mathrm{CDCl}_{3}\right) \delta 40.11$ (C20), 53.37 (C16, C19), 55.99 (C14), 58.93 (C15), 66.86 (C17, C18), 112.00 (C12), 116.36 (C22), 122.88 (C10), 123.67 (C2, C6), 130.60 (C8),
131.20 (C3, C5), 135.47 (C9), 136.91 (C4), 137.01 (C21), 138.85 (C11), 150.69 (C1), 151.52 (C13), 162.62 (C7); MS MALDI-TOF $(\mathrm{m} / \mathrm{z})$ : calcd. for $\mathrm{C}_{22} \mathrm{H}_{24} \mathrm{~N}_{2} \mathrm{O}_{6}[\mathrm{M}+\mathrm{H}]^{+}$: 413.17, found: 413.49 .

4-Allyl-2-methoxy-6-(morpholin-4-ylmethyl)phenyl 4-methylbenzoate (4c)

From 4-methylbenzoyl chloride. Yellow solid; yield 93\%; mp 70-73 ${ }^{\circ} \mathrm{C}$; IR (ATR) $\overline{\mathrm{v}}_{\max } / \mathrm{cm}^{-1} 3001,2852,2802$, 1738, 1610, 1595, 1490, 1463, 1350, 1261, 1197, 1113, 1062, 1010, 910; ${ }^{1} \mathrm{H}$ NMR (300 MHz, $\left.\mathrm{CDCl}_{3}\right) \delta$ 8.12-8.09 (m, 2H, H3, H5), 7.31-7.29 (m, 2H, H2, H6), 6.80 (s, 1H, $\mathrm{H} 10), 6.77$ (s, 1H, H12), 6.05-5.91 (m, 1H, H21, $J_{\mathrm{H} 21-\mathrm{H} 20}$ $\left.6.72 \mathrm{~Hz}, J_{\mathrm{H} 21-\mathrm{H} 22 \text { cis }} 10.11 \mathrm{~Hz}, J_{\mathrm{H} 21-\mathrm{H} 22 \text { trans }} 16.91 \mathrm{~Hz}\right), 5.15-5.10$ (m, 2H, H22), 3.80 (s, 3H, H14), 3.47-3.38 (m, 8H, H15, H17, H18, H20, $J_{\mathrm{H} 20-\mathrm{H} 21} 6.69 \mathrm{~Hz}$ ), 2.45 (s, 3H, H23), 2.32 (m, 4H, H16, H19); $\left.{ }^{13} \mathrm{C} \mathrm{NMR} \mathrm{(75} \mathrm{MHz,} \mathrm{CDCl}_{3}\right) \delta 21.74$ (C23), 40.15 (C20), 53.37 (C16, C19), 55.99 (C14), 58.37 (C15), 66.71 (C17, C18), 111.82 (C12), 116.13 (C22), 122.49 (C10), 127.11 (C4), 129.20 (C2, C6), 130.23 (C3, C5), 130.87 (C8), 137.16 (C21), 137.49 (C9), 138.17 (C11), 143.98 (C1), 151.74 (C13), 164.47 (C7); MS MALDI-TOF $(\mathrm{m} / z)$ : calcd. for $\mathrm{C}_{23} \mathrm{H}_{27} \mathrm{NO}_{4}[\mathrm{M}+\mathrm{H}]^{+}: 382.20$, found: 382.48 .

4-Allyl-2-methoxy-6-(morpholin-4-ylmethyl)phenyl 4-methoxybenzoate (4d)

From 4-methoxybenzoyl chloride. White solid; yield 90\%; mp 86-89 ${ }^{\circ} \mathrm{C}$; IR (ATR) $\overline{\mathrm{v}}_{\max } / \mathrm{cm}^{-1} 3000,2957$, 2837, 1723, 1601, 1508, 1489, 1462, 1253, 1160, 1115, 1068, 1007, 915; ${ }^{1} \mathrm{H}$ NMR (300 MHz, $\left.\mathrm{CDCl}_{3}\right) \delta 8.19-8.15$ (m, 2H, H3, H5), 6.99-6.96 (m, 2H, H2, H6), 6.80 (s, 1H, H10), 6.76 (s, 1H, H12), 6.05-5.91 (m, 1H, H21, $\left.J_{\mathrm{H} 21-\mathrm{H} 20} 6.69 \mathrm{~Hz}, J_{\mathrm{H} 21-\mathrm{H} 22 c i s} 10.11 \mathrm{~Hz}, J_{\mathrm{H} 21-\mathrm{H} 22 \text { trans }} 13.91 \mathrm{~Hz}\right)$, 5.15-5.08 (m, 2H, H22), 3.89 (s, 3H, H23), 3.80 (s, 3H, H14), 3.47-3.38 (m, 8H, H15, H17, H18, H20, $J_{\mathrm{H} 20-\mathrm{H} 21}$ $6.69 \mathrm{~Hz}), 2.32$ (m, 4H, H16, H19); ${ }^{13} \mathrm{C} \mathrm{NMR} \mathrm{(75} \mathrm{MHz,}$ $\left.\mathrm{CDCl}_{3}\right) \delta 40.15$ (C20), 53.40 (C16, C19), 55.49 (C23), 55.99 (C14), 58.38 (C15), 66.75 (C17, C18), 111.78 (C12), 113.74 (C2, C6), 116.11 (C22), 122.25 (C4), 122.45 (C10), 130.99 (C8), 132.26 (C3, C5), 137.18 (C21), 137.50 (C9), 138.11 (C11), 151.79 (C13), 163.63 (C7), 164.14 (C1); MS MALDI-TOF $(\mathrm{m} / \mathrm{z})$ : calcd. for $\mathrm{C}_{23} \mathrm{H}_{27} \mathrm{NO}_{5}[\mathrm{M}+\mathrm{H}]^{+}:$398.20, found: 398.57 .

4-Allyl-2-methoxy-6-(morpholin-4-ylmethyl)phenyl 4-bromobenzoate (4e)

From 4-bromobenzoyl chloride. Yellow solid; yield 76\%; mp 85-111 ${ }^{\circ} \mathrm{C}$; IR (ATR) $\overline{\mathrm{v}}_{\max } / \mathrm{cm}^{-1} 3072,2953$, 2853, 2803, 1737, 1589, 1492, 1452, 1396, 1262, 1144, 1113, 1072, 1009, 909, 747; ${ }^{1} \mathrm{H}$ NMR (300 MHz, $\mathrm{CDCl}_{3}$ ) 


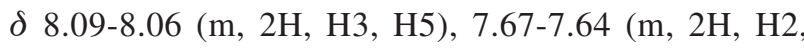
H6), 6.78 (s, 2H, H10, H12), 6.04-5.92 (m, 1H, H21, $\left.J_{\mathrm{H} 21-\mathrm{H} 20} 6.72 \mathrm{~Hz}, J_{\mathrm{H} 21-\mathrm{H} 22 \text { cis }} 10.14 \mathrm{~Hz}, J_{\mathrm{H} 21-\mathrm{H} 2 \text { trans }} 16.88 \mathrm{~Hz}\right)$, 5.15-5.09 (m, 2H, H22), 3.80 (s, 3H, H14), 3.40-3.38 (m, $\left.8 \mathrm{H}, \mathrm{H} 15, \mathrm{H} 17, \mathrm{H} 18, \mathrm{H} 20, J_{\mathrm{H} 20-\mathrm{H} 21} 6.72 \mathrm{~Hz}\right), 2.29$ (m, 4H, H16, H19); ${ }^{13} \mathrm{C}$ NMR $\left(75 \mathrm{MHz}, \mathrm{CDCl}_{3}\right) \delta 40.14(\mathrm{C} 20)$, 53.40 (C16, C19), 55.99 (C14), 58.70 (C15), 66.71 (C17, C18), 111.87 (C12), 116.23 (C22), 122.55 (C10), 128.38 (C1), 128.89 (C4), 130.86 (C8), 131.66 (C2, C6), 131.86 (C3, C5), 137.06 (C21), 137.24 (C9), 138.45 (C11), 151.65 (C13), 163.90 (C7); MS MALDI-TOF $(\mathrm{m} / \mathrm{z})$ : calcd. for $\mathrm{C}_{22} \mathrm{H}_{24} \mathrm{NO}_{4} \mathrm{Br}[\mathrm{M}+\mathrm{H}]^{+}: 446.10$, found: 446.33 .

\section{4-Allyl-2-methoxy-6-(morpholin-4-ylmethyl)phenyl} 4-(trifluoromethyl)benzoate (4f)

From 4-(trifluoromethyl)benzoyl chloride. White solid; yield $82 \%$; mp 82-87 ${ }^{\circ} \mathrm{C}$; IR (ATR) $\overline{\mathrm{v}}_{\max } / \mathrm{cm}^{-1} 3078,2969$, 2855, 1743, 1598, 1491, 1456, 1351, 1263, 1166, 1115, $1063,1015,911 ;{ }^{1} \mathrm{H}$ NMR $\left(300 \mathrm{MHz}, \mathrm{CDCl}_{3}\right) \delta 8.35-8.32$ $(\mathrm{d}, 2 \mathrm{H}, \mathrm{H} 3, \mathrm{H} 5, J 8.07 \mathrm{~Hz}), 7.79-7.76(\mathrm{~d}, 2 \mathrm{H}, \mathrm{H} 2, \mathrm{H} 6$, $J 8.16 \mathrm{~Hz}$ ), 6.79 (s, 2H, H10, H12), 6.05-5.91 (m, 1H, H21, $\left.J_{\mathrm{H} 21-\mathrm{H} 20} 6.72 \mathrm{~Hz}, J_{\mathrm{H} 21-\mathrm{H} 22 c i s} 10.17 \mathrm{~Hz}, J_{\mathrm{H} 21-\mathrm{H} 22 \text { trans }} 16.85 \mathrm{~Hz}\right)$, 5.16-5.10 (m, 2H, H22), 3.81 (s, 3H, H14), 3.41-3.39 (m, 8H, H15, H17, H18, H20), 2.29 (m, 4H, H16, H19); ${ }^{13} \mathrm{C}$ NMR $\left(75 \mathrm{MHz}, \mathrm{CDCl}_{3}\right) \delta 40.13(\mathrm{C} 20), 53.40$ (C16, C19), 55.97 (C14), 58.78 (C15), 66.66 (C17, C18), 111.91 (C12), 116.26 (C22), 121.83 (C4), 122.59 (C10), 125.56 (C2, C6), 127.02, 130.77, 134.91 and 138.62 (C23, J 290.07 Hz), 130.52 (C3, C5), 133.26 (C8), 134.48 (C9), 137.00 (C21), 137.15 (C11), 151.59 (C13), 163.25 (C7); MS MALDI-TOF $(\mathrm{m} / \mathrm{z})$ : calcd. for $\mathrm{C}_{23} \mathrm{H}_{24} \mathrm{NO}_{4} \mathrm{~F}_{3}[\mathrm{M}+\mathrm{H}]^{+}$: 436.17, found: 436.43 .

\section{4-Allyl-2-methoxy-6-(morpholin-4-ylmethyl)phenyl 4-tert-butylbenzoate $\mathbf{( 4 g})$}

From 4-tert-butylbenzoyl chloride. White solid; yield 53\%; mp 79-85 ${ }^{\circ} \mathrm{C}$; IR (ATR) $\overline{\mathrm{v}}_{\max } / \mathrm{cm}^{-1} 2959,2865,2804$, 1736, 1608, 1489, 1454, 1351, 1265, 1183, 1110, 1065, 1012,$910 ;{ }^{1} \mathrm{H}$ NMR $\left(300 \mathrm{MHz}, \mathrm{CDCl}_{3}\right) \delta 8.15-8.13(\mathrm{~d}, 2 \mathrm{H}$, H3, H5, J 7.14 Hz), 7.53-7.50 (m, 2H, H2, H6, J 7.02 Hz), 6.82 (s, 1H, H10), 6.76 (s, 1H, H12), 6.02-5.94 (m, 1H, H21), 5.15-5.08 (m, 2H, H22), 3.79 (s, 3H, H14), 3.47-3.39 (m, 8H, H15, H17, H18, H20), 2.33 (m, 4H, H16, H19), 1.37 (s, 9H, H24, H25, H26); ${ }^{13} \mathrm{C} \mathrm{NMR} \mathrm{(75} \mathrm{MHz,} \mathrm{CDCl}_{3}$ ) $\delta 31.15$ (C24, C25, C26), 35.18 (C23), 40.16 (C20), 53.41 (C16, C19), 55.98 (C14), 58.21 (C15), 66.71 (C17, C18), 111.77 (C12), 116.11 (C22), 122.42 (C10), 125.47 (C2, C6), 127.02 (C4), 130.09 (C3, C5), 130.93 (C8), 137.18 (C21), 137.47 (C9), 138.17 (C11), 151.71 (C13), 157.01 (C1), 164.41 (C7); MS MALDI-TOF $(\mathrm{m} / \mathrm{z})$ : calcd. for $\mathrm{C}_{26} \mathrm{H}_{33} \mathrm{NO}_{4}[\mathrm{M}+\mathrm{H}]^{+}:$424.25, found: 424.55 .
4-Allyl-2-methoxy-6-(morpholin-4-ylmethyl)phenyl 4-fluorobenzoate (4h)

From 4-fluorobutilmetilbenzoyl chloride. White solid; yield 80\%; mp 95-98 ${ }^{\circ} \mathrm{C}$; IR (ATR) $\overline{\mathrm{v}}_{\max } / \mathrm{cm}^{-1} 2955,2921$, 2850, 2812, 1738, 1596, 1505, 1263, 1197, 1110, 1068, 1010; ${ }^{1} \mathrm{H}$ NMR $\left(300 \mathrm{MHz}, \mathrm{CDCl}_{3}\right) \delta 8.26-8.21(\mathrm{~m}, 2 \mathrm{H}$, H3, H5), 7.26-7.15 (m, 2H, H2, H6), 6.79 (s, 1H, H10), 6.78 (s, 1H, H12), 6.05-5.92 (m, 1H, H21, $J_{\mathrm{H} 21-\mathrm{H} 20} 6.75 \mathrm{~Hz}$, $\left.J_{\mathrm{H} 21-\mathrm{H} 22 c i s} 10.11 \mathrm{~Hz}, J_{\mathrm{H} 21-\mathrm{H} 22 \text { trans }} 16.88 \mathrm{~Hz}\right), 5.16-5.09(\mathrm{~m}, 2 \mathrm{H}$, H22), 3.80 (s, 3H, H14), 3.44-3.38 (m, 8H, H15, H17, H18, $\left.\mathrm{H} 20, J_{\mathrm{H} 20-\mathrm{H} 21} 6.72 \mathrm{~Hz}\right), 2.30$ (m, 4H, H16, H19); ${ }^{13} \mathrm{C}$ NMR $\left(75 \mathrm{MHz}, \mathrm{CDCl}_{3}\right) \delta 40.1(\mathrm{C} 20), 53.4(\mathrm{C} 16, \mathrm{C} 19), 56.0$ (C14), 58.6 (C15), 66.7 (C17, C18), 111.9 (C12), 115.5 and $115.8(\mathrm{C} 2, \mathrm{C} 6, J 22.5 \mathrm{~Hz}), 116.2(\mathrm{C} 22), 122.5(\mathrm{C} 10)$, 126.2 (C4), 130.86 (C8), 132.7 (C3, C5), 137.1 (C21), 137.3 (C9), 138.6 (C11), 151.7 (C13), 163.5 and 167.6 (C1, $J 307.5 \mathrm{~Hz}), 164.3(\mathrm{C} 7)$; MS MALDI-TOF $(\mathrm{m} / \mathrm{z})$ : calcd. for $\mathrm{C}_{22} \mathrm{H}_{24} \mathrm{NO}_{4} \mathrm{~F}[\mathrm{M}+\mathrm{H}]^{+}: 386.18$, found: 386.44 .

\section{4-Allyl-2-methoxy-6-(morpholin-4-ylmethyl)phenyl 4-aminobenzoate (4i)}

Reduction of the nitro group to the amine for the synthesis of the 4-allyl-2-methoxy-6-(morpholin4-ylmethyl)phenyl-4-aminobenzoate was based on the methods described by Gamble et al. ${ }^{18}$ and Bellamy and Ou. ${ }^{19}$

Into a round bottom flask containing $0.223 \mathrm{~g}$ of compound $4 \mathbf{b}$ ( $0.54 \mathrm{mmol}), 5 \mathrm{~mL}$ of absolute ethanol and $1.22 \mathrm{~g}$ of $\mathrm{SnCl}_{2} \cdot 2 \mathrm{H}_{2} \mathrm{O}(5.41 \mathrm{mmol})$ were added. The reaction was conducted in an ultrasonic bath under periodic stirring at room temperature and in an atmosphere of argon for $16 \mathrm{~min}$.

The reaction was monitored by TLC (hexane/ethyl acetate $6: 4, v / v)$. After completion of the reaction, the medium was neutralized to approximately $\mathrm{pH} 7$ with saturated sodium bicarbonate solution over crushed ice, and an extraction was then performed with ethyl acetate. The organic phase was dried with anhydrous $\mathrm{Na}_{2} \mathrm{SO}_{4}$ and filtered. The filtrate was then concentrated using a rotary evaporator. The product was purified by CC (ethyl acetate/ hexane 3:7, v/v).

Yellow oil; yield 49\%; IR (ATR) $\bar{v}_{\max } / \mathrm{cm}^{-1} 3465$, 3362, 3227, 2958, 2806, 1712, 1625, 1598, 1517, 1489, 1454, 1351, 1264, 1167, 1111, 1065, 1008, 908; ${ }^{1} \mathrm{H}$ NMR (300 MHz, $\left.\mathrm{CDCl}_{3}\right) \delta$ 8.02-7.99 (m, 2H, H3, H5), 6.81 (s, 1H, H10), 6.75 (s, 1H, H12), 6.69-6.67 (m, 2H, H2, H6), 6.04-5.92 (m, 1H, H21, $J_{\mathrm{H} 21-\mathrm{H} 20} 6.72 \mathrm{~Hz}, J_{\mathrm{H} 21-\mathrm{H} 22 c i s} 10.11 \mathrm{~Hz}$, $\left.J_{\mathrm{H} 21-\mathrm{H} 22 \text { trans }} 16.94 \mathrm{~Hz}\right), 5.14-5.08(\mathrm{~m}, 2 \mathrm{H}, \mathrm{H} 22), 4.14(\mathrm{~s}, 2 \mathrm{H}$, $\mathrm{NH}_{2}$ ), 3.79 (s, 3H, H14), 3.51 (m, 6H, H15, H17, H18), 3.39-3.37 (d, 2H, H20, J 6.69 Hz), 2.35 (m, 4H, H16, H19); ${ }^{13} \mathrm{C}$ NMR $\left(75 \mathrm{MHz}, \mathrm{CDCl}_{3}\right) \delta 40.16(\mathrm{C} 20), 53.37$ (C16, 
C19), 56.0 (C14), 58.1 (C15), 66.75 (C17, C18), 111.75

(C12), 113.84 (C2, C6), 116.08 (C22), 119.07 (C4), 122.41

(C10), 130.93 (C8), 132.32 (C3, C5), 137.23 (C21), 137.62

(C9), 137.96 (C11), 151.24 (C13), 151.83 (C1), 164.44

(C7); MS MALDI-TOF $(\mathrm{m} / \mathrm{z})$ : calcd. for $\mathrm{C}_{22} \mathrm{H}_{24} \mathrm{~N}_{2} \mathrm{O}_{6}$ $[\mathrm{M}+\mathrm{H}]^{+}:$383.20, found: 383.49 .

Inhibitory activity against rCPB 2.8

The procedure was performed using $1 \mathrm{~mL}$ of $100 \mathrm{mmol} \mathrm{L}^{-1}$ sodium acetate buffer ( $\mathrm{pH} 5.5$, containing $5 \mathrm{mmol} \mathrm{L}^{-1}$ EDTA, $100 \mathrm{mmol} \mathrm{L}^{-1} \mathrm{NaCl}, 20 \%$ glycerol and $0.01 \%$ triton $\mathrm{X}-100$ ), to which $3 \mathrm{mmol} \mathrm{L}^{-1}$ dithiothreitol (DTT) and enzyme were added. The mixture was left to pre-activate for $10 \mathrm{~min}$, then the fluorogenic substrate Z-FR MCA $\left(7.4 \mu \mathrm{mol} \mathrm{L}^{-1}\right)$ was added. The enzymatic activity was monitored by substrate hydrolysis at $360 \mathrm{~nm}$ excitation and $480 \mathrm{~nm}$ emission wavelengths in a spectrofluorimeter. The reaction solution was continuously stirred and the temperature maintained at $37^{\circ} \mathrm{C}$ in thermostatically-controlled water bath. The values of the enzymatic activity were calculated by linear regression and expressed as UAF min $^{-1}$ (arbitrary units of fluorescence per minute).

The assays were repeated with two different concentrations (10 and $100 \mu \mathrm{mol} \mathrm{L}^{-1}$ ) of each compound, enabling the activity values in UAF $\mathrm{min}^{-1}$ to be determined for each one. The values obtained in the absence of the compound were assumed to represent $100 \%$ activity, and the activity values in the presence of the compounds were calculated as a proportion of these values.

Enzyme inhibition was expressed as the compound concentration causing a $50 \%$ decrease in enzyme activity ( $\mathrm{IC}_{50}$ value). $\mathrm{IC}_{50}$ value was calculated by non-linear regression, based on dose-response curves using $\mathbf{4 b}$ compound at different concentrations, and the data were analyzed with Grafit 5.0 software ${ }^{20}$ using equation 1:

$$
y=\frac{100 \%}{1+\left(\frac{\mathrm{x}}{\mathrm{IC}_{50}}\right)^{\mathrm{s}}}
$$

In equation $1, \mathrm{y}$ is the enzyme activity, $\mathrm{x}$ is the inhibitor concentration, and $\mathrm{s}$ is a slope factor. The equation assumes that $\mathrm{y}$ reduces with increasing $\mathrm{x}$.

\section{In vitro cytotoxicity assay}

For the evaluation of cytotoxicity and cell viability, macrophages were collected from the peritoneal cavity of Swiss mice by peritoneal lavage with sterile phosphatebuffered saline (PBS). The compounds were diluted in dimethyl sulfoxide (DMSO) and serially diluted into 96-well culture plates containing RPMI-1640 medium supplemented with $10 \%$ fetal bovine serum (in triplicate), with the concentration ranging from 100 to $0.781 \mu \mathrm{g} \mathrm{mL}^{-1}$. The macrophages were then added at a concentration of $5 \times 10^{5}$ cells well ${ }^{-1}$. The assay plates were incubated for $48 \mathrm{~h}$ at $37{ }^{\circ} \mathrm{C}$ in a $5 \% \mathrm{CO}_{2}$ incubator, and cell viability was determined by the 3-(4,5-dimethylthiazol-2-yl)2,5-diphenyltetrazolium bromide (MTT) colorimetric assay as described above. ${ }^{21}$ The drug amphotericin B was used as a positive control in the assay. The cytotoxic concentration to $50 \%$ of the macrophages $\left(\mathrm{CC}_{50}\right)$ was determined by measuring optical density $(570 \mathrm{~nm})$.

\section{Homology modeling}

A cysteine protease rCPB 2.8 primary sequence with 443 amino acids (NCBI Protein: P36400) was used for the prediction of the three-dimensional (3D) structure of the protein, which was subjected to sequence comparisons and homology modeling. The region between the amino acid residues 122 and 337 was used for the construction of a 3D model as it corresponds to the amino acid sequence that comprises the active and most stable form of the enzyme at its site of action, removing the regions $\mathrm{C}$ - and $\mathrm{N}$-terminals that are not essential for activity. ${ }^{6}$

The construction of the homology model for the rCPB 2.8 protein started with the search for homologous proteins with a degree of sequential identity with rCPB 2.8, obtained by the local alignment of sequences whose corresponding 3D structures are known (usually through X-ray crystallography or NMR spectroscopy) using the basic local alignment search tool program algorithm (BLAST). ${ }^{22}$ Two crystallographic structures (PDB code: 3IUT and 2P7U) present in the Protein Data Bank (PDB) database, which had good resolution and distribution of the residues in the Ramachandran plot, ${ }^{23}$ were selected. The global alignment of multiple sequences between the target sequence and the templates was performed by the Clustal Omega $^{24}$ program to demonstrate the degree of similarity between the sequences, and is illustrated in Figure 1.

The comparative modeling software MODELLER ${ }^{25}$ version 9.16 was used to design the most probable $3 \mathrm{D}$ models by optimally satisfying spatial restraints derived from the alignment. One hundred 3D models were designed and the selection of the best model was performed using the PROCHECK ${ }^{26}$ program selecting the structure with the best stereochemical quality, with the higher amount of amino acid residues in favorable and allowed regions and lower number of amino acids in unfavorable regions in the Ramachandran plot. The model was validated and 


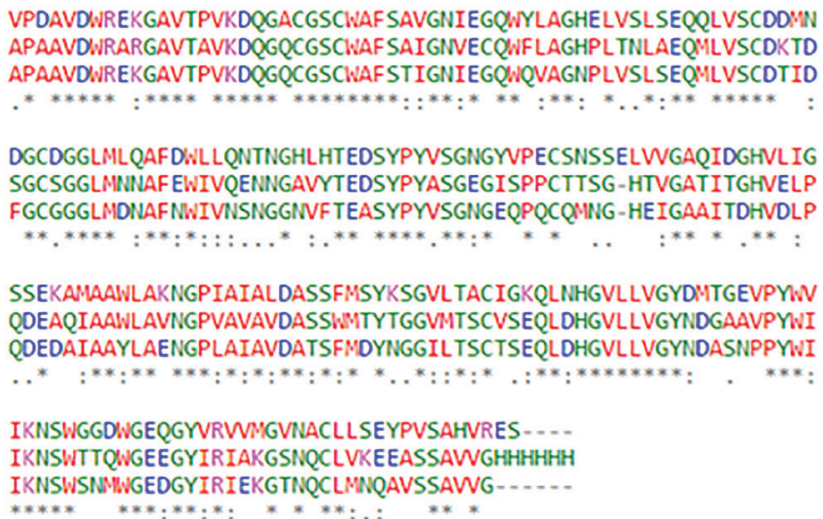

VPDAVDWREKGAVTPVKDQGACGSCWAFSAVGNIEGQWYLAGHELVSLSEQQLVSCDOMN APAAVDWRARGAVTAVKDQGQCGSCWAFSAIGNVECQWFLAGHPLTNLAEQMLVSCDKTD APAAVDWREKGAVTPVKDQGQCGSCWAFSTIGNIEGQWQVAGNPLVSLSEQMLVSCDTID

DGCDGGLMLOAFDWLLONTNGHLHTEDSYPYSGNGYPECSNSSELWGAQIDGHVLIG SGCSGGLMNNAFEWIVQENNGAVYTEDSYPYASGEGISPPCTTSG-HTVGATITGHVELP FGCGGGLMDNAFNWIVNSNGGNVFTEASYPYVSGNGEQPQCOMNG - HEIGAAITDHVDLP

SSEKAMAAWLAKNGPIAIALDASSFMSYKSGVLTACIGKOLNHGVLLVGYDMTGEVPYN QDEAQIAAWLAVNGPVAVAVDASSWMTYTGGVMTSCVSEQLOHGVLLVGYNDGAAVPYWI QDEDAIAAYLAENGPLAIAVDATSFMOYNGGILTSCTSEQLDHGVLLVGYNDASNPPYWI

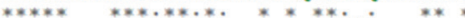

Figure 1. Multiple sequence alignment of rCPB 2.8 protein and templates (PDB code: 3IUT and 2P7U) performed by the Clustal Omega program. ${ }^{24}$

submitted to molecular dynamics simulation for a period of 10 ns to obtain a suitable structure for future molecular docking studies.

\section{Molecular dynamics as a method of refinement of homology- based protein structures}

A molecular dynamics (DM) simulation was performed using the GROMACS program 4.6.1 with the AMBER99SB22 force field. ${ }^{27-29}$ The prediction of the protonation state of the protein at $\mathrm{pH} 7$ was determined by $\mathrm{H}^{++}$server. ${ }^{30}$ The enzyme was centralized within a periodic and solvated box with 20,892 molecules of water, using the transferable intermolecular type with 3 points water model (TIP3P). The total charge of the medium was neutralized with sodium and chlorine ions at a 0.15 molar ionic strength.

A total energy minimization of the system was then performed with successive steps, using the algorithm "steepest descent position restrained" and a convergence criterion of $1000 \mathrm{~kJ} \mathrm{~mol}^{-1}$. The system was then subjected to an equilibration step in the canonical (NVT) ensemble and in the isothermal-isobaric (NPT) ensemble. The temperature was controlled using a v-rescale ${ }^{31}$ thermostat and the pressure was controlled using a ParrinelloRahman $^{32}$ barostat. Linear constraint solver ${ }^{33}$ (LINCS) algorithm constraints were applied to bonds involving hydrogen. Long-distance electrostatic interactions were treated using the particle-mesh Ewald ${ }^{34}$ (PME) algorithm and the cutoff distance applied to the van der Waals and Coulomb interactions was $1.2 \mathrm{~nm}$. DM simulation was performed for $10 \mathrm{~ns}$. From the molecular dynamics simulation trajectory, the overall deviation from the starting structure was measured by root-mean-square deviation (RMSD) and structure clustering was performed using RMSD with a cut-off value of $0.1 \AA$ as a similarity criterion between the structures.

\section{Molecular docking}

Molecular docking analysis was performed using the Schrödinger software suite for the active site and all possible interactions sites found for rCPB 2.8 model using SiteMap ${ }^{35}$ program.

For ligand preparation, the LigPrep program was used with OPLS_3 force field and ionization state for pH $7.0 \pm 2.0$ (using Epik). ${ }^{36}$ The protein structures preparation was realized by the Protein Preparation Wizard program with the minimization performed using the OPLS-3 force field in the macromodel module. ${ }^{37}$

For the docking analysis, the induced fit docking (IFD) protocol was used, which performed the prediction of the protein structure and the refinement of the compounds using the Prime program, as well as the docking and provides the score by the Glide program, considering the protein and the ligand flexible. ${ }^{38}$ The grid box area was defined as $20 \times 20 \times 20 \AA$. The force field used was OPLS_3. The final ligand-protein complexes were visualized using the Maestro $^{39}$ version 10.2.010 interface, and figures were generated using its graphical interface and $\mathrm{Pymol}^{40}$ software.

\section{Results and Discussion}

\section{Chemistry}

The synthetic route used for obtention of esters of eugenol (4a-i) is represented in Scheme 1. The natural product eugenol (1) was converted into its morpholine derivative (2) with the aim of increasing the affinity of compounds to the enzyme rCPB 2.8 due to their preferential affinity for substrates of basic character, followed by esterification reaction with acid chlorides $(\mathbf{3 a} \mathbf{a}-\mathbf{h})$ to obtain the final compounds (4a-i) proposed.

Compound 2 was obtained by the Mannich reaction from eugenol (1), formaldehyde and morpholine, with 


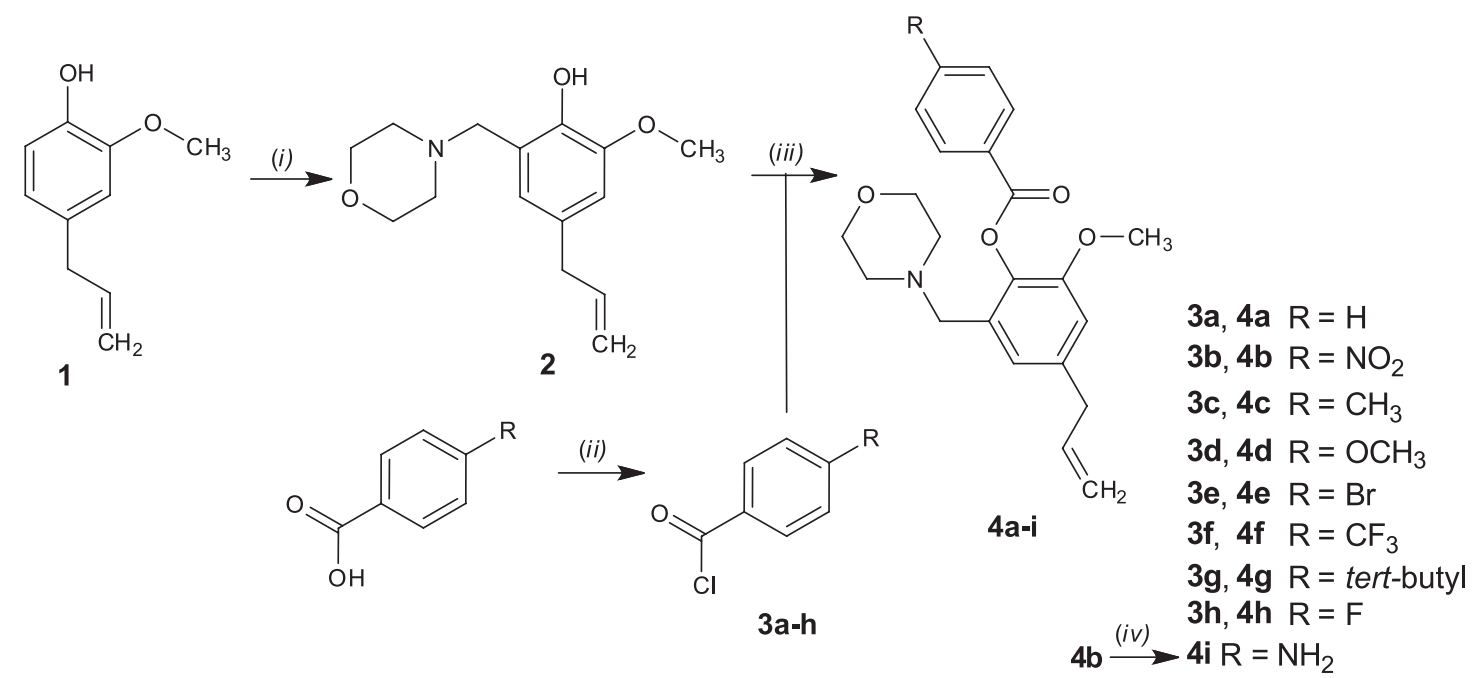

Scheme 1. General scheme used for the preparation of eugenol esters. Reagents, conditions and yields: $(i)$ morpholine, formaldehyde, toluene, $95{ }^{\circ} \mathrm{C}($ yield $50 \%$ ); (ii) thionyl chloride, $80{ }^{\circ} \mathrm{C}$; (iii) acyl chloride (3a-h), 4-dimethylaminopyridine, dichloromethane, r.t. (variable yield); (iv) $\mathrm{SnCl}_{2} \cdot 2 \mathrm{H}_{2} \mathrm{O}, \mathrm{ethanol}$, ultrasonic bath irradiation, argon, r.t. (yield 49\%).

posterior electrophilic aromatic substitution between the iminium intermediary ion formed and the aromatic ring of eugenol, with $50 \%$ yield. The IR spectrum showed characteristic bands in $3297 \mathrm{~cm}^{-1}$ relative to O-H stretch, $1659 \mathrm{~cm}^{-1}$ relative to $\mathrm{C}=\mathrm{C}$ stretch of alkyne bonds, besides an intense band at $1072 \mathrm{~cm}^{-1}$ relative to the ether $\mathrm{C}-\mathrm{O}$ bond stretch. The band relative to the $\mathrm{C}-\mathrm{N}$ aliphatic stretch at $1111 \mathrm{~cm}^{-1}$ confirmed the insertion of the morpholine ring in the eugenol structure.

The acid chlorides (3a-h) used in the esterification step were prepared from its carboxylic acids derivatives by reaction of nucleophilic substitution between the sulfur atom content of thionyl chloride and the lone pair of electrons of the oxygen atom of $p$-substituted benzoic acids derivatives, and between the carbonyl group of the intermediate formed and the chloride ion. Due to chemical instability of intermediaries obtained, the subsequent reaction was performed without the structural characterization of these compounds.

The last step consisted of the esterification reaction between compound $\mathbf{2}$ and the acid chlorides $(\mathbf{3 a}-\mathbf{h})$ that occurred with the use of dichloromethane and DMAP in room temperature. The reactional yield ranged between 29 and $93 \%$ due to the reactivity of acid chloride used as reagent.

The synthesis of the compound $\mathbf{4} \mathbf{i}$ was performed through reduction of the nitro group of compound $\mathbf{4 b}$ with the use of hydrated tin chloride and ethanol in an ultrasound bath, providing the amino compound $\mathbf{4 i}$ at a yield of $49 \%$. The mechanism involved the transfer of electrons by the tin atom of $\mathrm{SnCl}_{2} .2 \mathrm{H}_{2} \mathrm{O}$ with the formation of the nitroso intermediate and hydroxylamine. ${ }^{41}$

The characterization of the esters synthesized was performed using analysis of the IR and NMR spectra. IR spectra of compounds 4a-i demonstrated the presence of a band at $1742 \mathrm{~cm}^{-1}$ for the carbonyl group, which showed formation of the ester group. ${ }^{1} \mathrm{H}$ NMR spectra showed all the signs of hydrogen atoms of the aromatic ring between the chemical shift of 6.5 to $8.5 \mathrm{ppm}$, multiplets of hydrogen atoms of the alkene at approximately 6 and $5.15 \mathrm{ppm}$, the sign of hydrogen atoms of the methoxyl group at $3.80 \mathrm{ppm}$ and signs of methylene hydrogen atoms in the region between 2 and $3.5 \mathrm{ppm} .{ }^{13} \mathrm{C}$ NMR spectra showed signs of carbon atoms of the morpholine ring in the region of further shielding and of greater intensity at approximately 66 and $53 \mathrm{ppm}$, confirmed by a subspectrum of distortionless enhancement by polarization transfer (DEPT), as well as signs of carbon atoms of alkene and methoxyl groups in this region, carbon atoms of alkene and aromatic rings in the region between 100 and $160 \mathrm{ppm}$ and the signal of the carbonyl carbon in the region of further deshielding at approximately $164 \mathrm{ppm}$.

\section{Inhibitory activity against rCPB 2.8}

The assay of inhibitory activity against rCPB 2.8 was performed for the $\mathbf{4 a - i}$ derivatives. The results (Table 1) showed potential inhibition of the enzyme by $\mathbf{4 b}$ (inhibiting $88.2 \%$ of the enzyme activity, $11.8 \%$ of the enzyme activity remaining) and, with less potency, $\mathbf{4 h}$ (inhibiting $28.3 \%$ of the enzyme activity, $71.8 \%$ of the enzyme activity remaining) at a concentration of $100 \mu \mathrm{M}$. Compounds $4 \mathbf{e}$ and $\mathbf{4 h}$, substances containing halogen as a substituent, were the least cytotoxic compounds with the highest $\mathrm{CC}_{50}$ value in macrophages from the peritoneal cavity of Swiss mice.

As the compound $\mathbf{4 b}$ was the most effective in terms of enzyme inhibition, the $\mathrm{IC}_{50}$ value was calculated using 
Table 1. Evaluation of the inhibitory activity against the enzyme rCPB 2.8 of the compounds $\mathbf{2}$ and $\mathbf{4 a - i}$, demonstrated by measuring enzyme activity values at concentrations of 10 and $100 \mu \mathrm{mol} \mathrm{L}^{-1}$ of each compound and control, and cytotoxicity in macrophages (with a 95\% confidence interval by statistical analysis, $\mathrm{CI}$ )<smiles>C=CCc1cc(CN2CCOCC2)c(O)c(OC)c1</smiles>

2<smiles>[R]c1ccc(C(=O)Oc2c(CN3CCOCC3)cc(CC=C)cc2OC)cc1</smiles>

$4 a-i$

\begin{tabular}{lccccc}
\hline Compound & $\mathrm{R}$ & $\begin{array}{c}\text { Enzymatic activity } \\
(\text { control }) / \%\end{array}$ & $\begin{array}{c}\text { Activity at } \\
10 \mu \mathrm{mol} \mathrm{L} / \%\end{array}$ & $\begin{array}{c}\text { Activity at } \\
100 \mu \mathrm{mol} \mathrm{L}^{-1} / \%\end{array}$ & $\begin{array}{c}\left.\mathrm{Cytotoxicity} \mathrm{CC}_{50} /(\mu \mathrm{\mu mol} \mathrm{L})^{-1}\right) \\
(\mathrm{CI})^{\mathrm{a}}\end{array}$ \\
\hline $\mathbf{2}$ & - & 100 & 111.6 & 211.3 & - \\
$\mathbf{4 a}$ & $\mathrm{H}$ & 100 & 109.8 & 95.7 & $20.55(12.06-35.00)$ \\
$\mathbf{4 b}$ & $\mathrm{NO}_{2}$ & 100 & 94.2 & 11.8 & $5.24(0.89-30.84)$ \\
$\mathbf{4 c}$ & $\mathrm{CH}_{3}$ & 100 & 141.0 & 151.5 & $31.46(22.41-44.15)$ \\
$\mathbf{4 d}$ & $\mathrm{OCH}_{3}$ & 100 & 97.1 & 92.8 & $16.25(5.23-50.47)$ \\
$\mathbf{4 e}$ & $\mathrm{Br}$ & 100 & 94.7 & 110.3 & $81.98(51.13-131.40)$ \\
$\mathbf{4 f}$ & $\mathrm{CF}_{3}$ & 100 & 147.1 & 133.3 & - \\
$\mathbf{4 g}$ & $t e r t-$ butyl & 100 & 95.4 & 96.2 & - \\
$\mathbf{4 h}$ & $\mathrm{F}$ & 100 & 139.8 & 71.8 & $103.83(72.23-149.29)$ \\
$\mathbf{4 i}$ & $\mathrm{NH}_{2}$ & 100 & 109.8 & 97.9 & - \\
\hline
\end{tabular}

${ }^{\mathrm{a} C I}$ : $95 \%$ confidence interval.

this compound. The $\mathrm{IC}_{50}$ value was $30 \pm 1 \mu \mathrm{mol} \mathrm{L} \mathrm{L}^{-1}$. Figure 2 shows the dose-response curve for compound $\mathbf{4 b}$ in different concentrations against rCPB 2.8 enzyme.

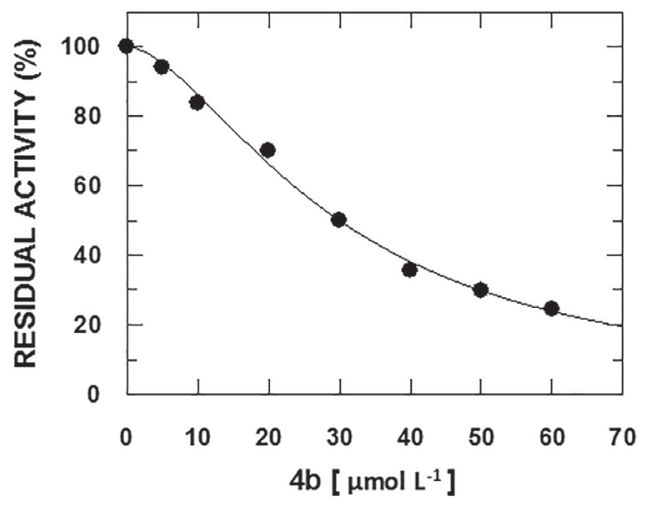

Figure 2. Inhibitory activity of compound $\mathbf{4 b}$ against rCPB2.8 enzyme.

The interaction profile with the enzyme at the active site and at allosteric sites was evaluated by molecular modeling studies and compared with the results of in vitro enzyme activity.

\section{Homology modeling}

The prediction model of rCPB 2.8 protein, obtained using Modeller software, ${ }^{25}$ showed good stereochemical quality after evaluation. The structure validation by carbon alpha geometry according to the Ramachandran plot showed $98.2 \%$ of the residues in favorable regions, $1.8 \%$ in allowed regions and $0 \%$ in unfavorable regions (Figure 3a). The Z-score score obtained (-7.11) indicates the overall quality of the model, shown in the Figure $3 b$ graph, containing the scores of all protein chains, determined experimentally by X-ray or NMR, in the current PDB database. Results from the Verify3D program ${ }^{42-44}$ show that most of the values obtained are within the acceptable range $(0.16$ and 0.8$)$ and $88.13 \%$ of the residues have a mean $3 \mathrm{D}-1 \mathrm{D}$ score greater than 0.2 , a value at which structural folding of the model is reliable. An RMSD value of $0.326 \AA$ was obtained for the alignment between the entire 3D structure of the rCPB 2.8 enzyme obtained by homology modeling and the cruzain enzyme (PDB code: 3IUT) used as a template (Figure 3c).

\section{Molecular dynamics simulation of rCPB 2.8 enzyme}

The 3D structure of the rCPB 2.8 enzyme obtained by molecular modeling remained stable throughout the molecular dynamics simulation, maintaining an RMSD value constant over time after $1 \mathrm{~ns}$ of simulation (Figure 4a). The center structure of the most populated cluster was selected for use in the molecular docking study (Figure 4b). 
(a)

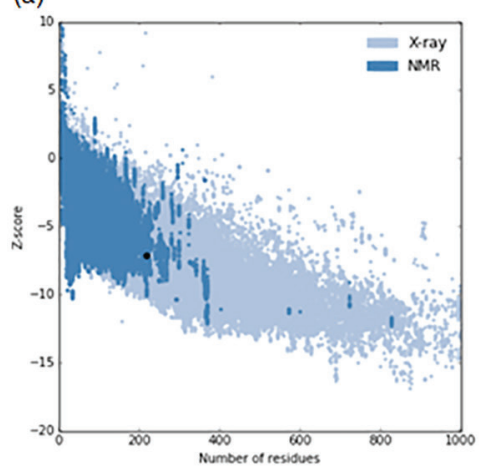

(c)

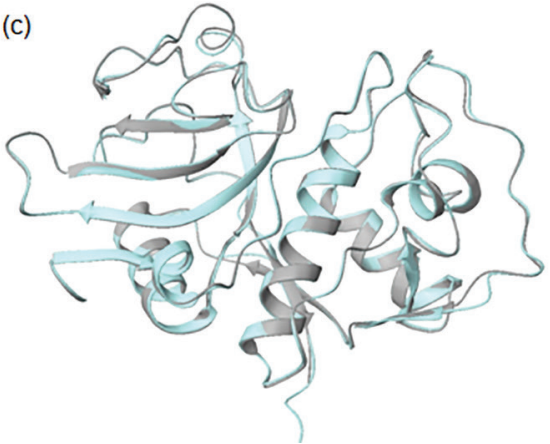

(b)

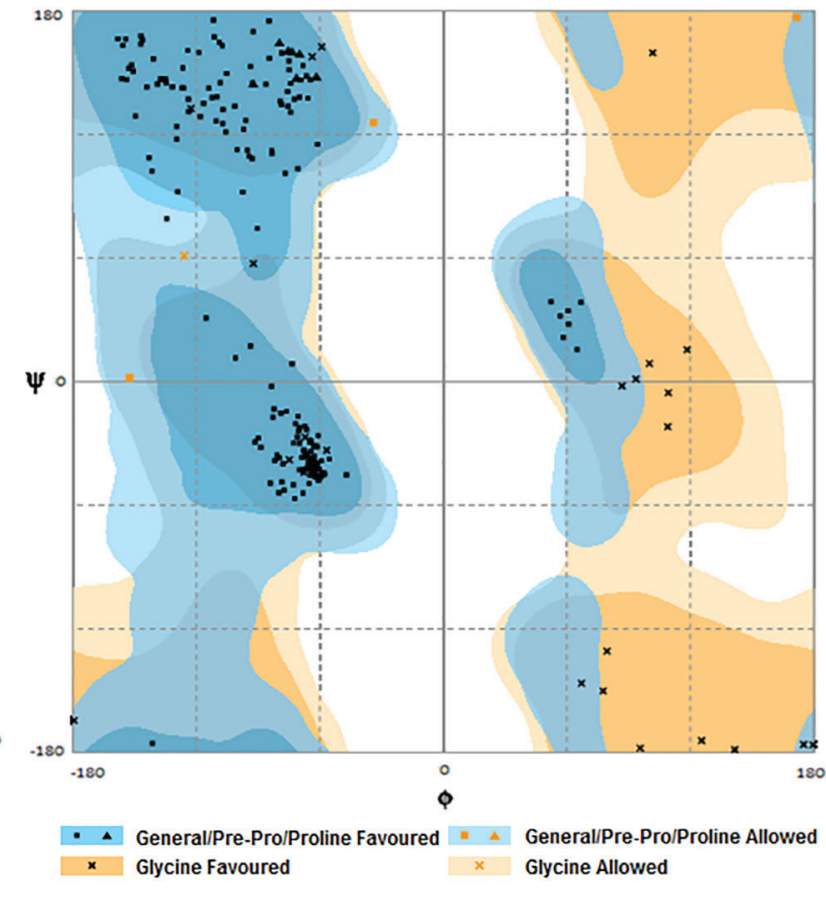

Figure 3. Model quality validation. (a) Z-score punctuation (-7.11) of the model; (b) Ramachandran plot; (c) superposition of the homology model of rCPB 2.8 with the structure of cruzain used as template (PDB code: $3 I U T)$.

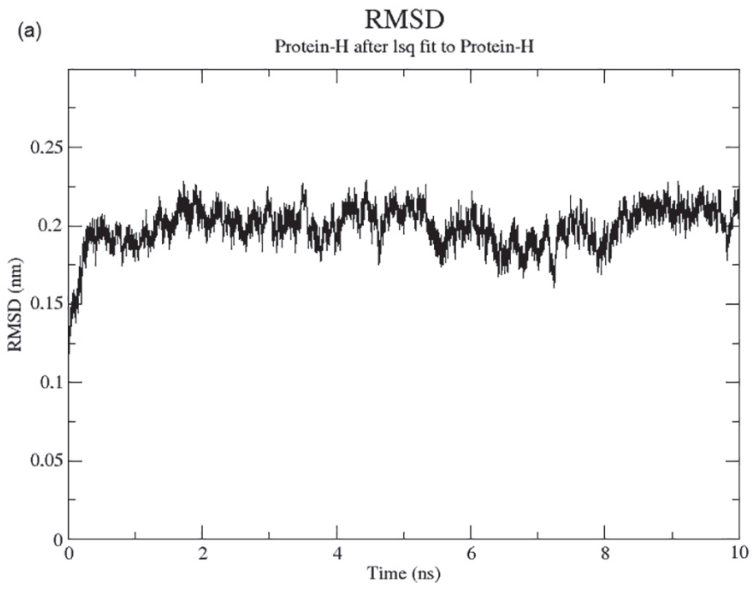

(b) Clusters

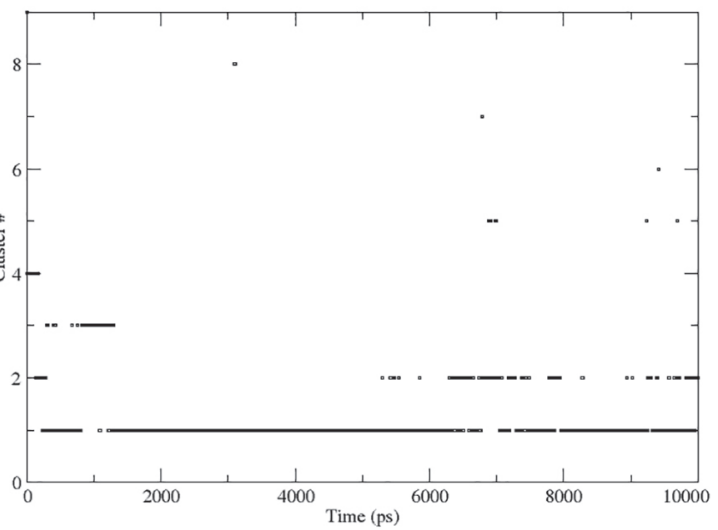

Figure 4. Simulation of molecular dynamics. (a) RMSD value calculated from the entire protein structure, except hydrogen atoms, obtained over time (ns); (b) cluster with approximate structures having low RMSD variation between them (cut-off value of $0.1 \AA$ ) throughout the DM simulation.

\section{Molecular docking}

After optimization of the model and relaxation by molecular dynamics, the molecular docking studies with the enzyme rCPB 2.8 against compounds 2 and $\mathbf{4 a - i}$ using IFD of Schrödinger-Maestro software ${ }^{39}$ were performed.

The glide score for the active site of the enzyme and the interaction sites on the surface of the protein are shown in Table 2.

The analysis of the glide score values verified that some compounds showed affinity with both the active site and the interaction site 1. It may indicate a mechanism developed by the organism to prevent compounds with affinity for the active site inhibiting the enzyme, connecting to the allosteric site due to some similarity between them. The preference and higher affinity of some compounds with the active site in relation to the interaction of these compounds with interaction site 1 led to the inhibition of that enzyme. The binding energy values (glide score) obtained show the preference of the compounds $4 \mathrm{a}, \mathbf{4 b}, \mathbf{4 d}, \mathbf{4 g}, \mathbf{4 h}$ and $4 \mathrm{i}$ for the active site of the enzyme. Among these compounds are those which have large substituted groups and which 
Table 2. Binding energies, represented as glide score, calculated by the induced fit docking (IFD) protocol (Schrödinger) program at all interaction sites

\begin{tabular}{|c|c|c|c|c|}
\hline \multirow{2}{*}{ Ligand } & \multicolumn{4}{|c|}{ Glide score / $\left(\mathrm{kcal} \mathrm{mol}^{-1}\right)$} \\
\hline & Active site & Interaction site 1 & Interaction site 2 & Interaction site 3 \\
\hline 2 & -5.445 & -5.820 & -4.820 & -4.374 \\
\hline $4 \mathbf{a}$ & -5.234 & -4.960 & -5.156 & -4.332 \\
\hline $4 b$ & -5.967 & -4.165 & -5.875 & -4.689 \\
\hline $4 c$ & -5.634 & $-\mathbf{5 . 7 5 3}$ & -5.114 & -4.315 \\
\hline $4 d$ & $-\mathbf{5 . 7 8 0}$ & -4.948 & -4.872 & -5.412 \\
\hline $4 e$ & -4.109 & -4.816 & -4.356 & -3.776 \\
\hline $4 f$ & -4.759 & -5.431 & -5.012 & -5.027 \\
\hline $4 \mathrm{~g}$ & -5.618 & -4.917 & -4.734 & -4.004 \\
\hline $4 h$ & -5.643 & -4.997 & -5.344 & -4.623 \\
\hline $4 \mathbf{i}$ & -6.248 & -5.252 & -4.474 & -4.718 \\
\hline
\end{tabular}

The best glide score obtained for each compound comparing all interaction sites is highlighted in bold.

have electronegative acceptor hydrogen bond groups. The compounds $\mathbf{2}, \mathbf{4 c}, \mathbf{4 e}$ and $\mathbf{4 f}$, which have small and lipophilic groups, showed preference for the interaction site 1 . The greater preference and selectivity of compound $4 \mathrm{~b}$ for the active site, demonstrated by the variation found between the value of affinity of this compound for the active site (glide score $-5.967 \mathrm{kcal} \mathrm{mol}^{-1}$ ) and the interaction site 1 (glide score $-4.165 \mathrm{kcal} \mathrm{mol}^{-1}$ ), not found for the other compounds, may have made compound $\mathbf{4 b}$ more active in the inhibition of the enzyme rCPB 2.8.

Evidence suggests that the great flexibility presented by enzymes containing allosteric sites may be somewhat more permissive in relation to the chemical structures attached to them, making it difficult to establish a relationship between the chemical structure of the ligands and the enzymatic activity. ${ }^{45}$

The four compounds that presented the best glide score values in the active site also showed inhibitory activity against enzyme rCPB 2.8 in vitro, but of different magnitudes, varying from low inhibitory activity to high activity. Compounds $\mathbf{4 b}$ and $\mathbf{4 h}$ showed considerable activity in vitro, inhibiting 88.2 and $28.3 \%$ of the enzymatic activity at a concentration of $100 \mu \mathrm{M}$, respectively. These compounds have an electronegative, electron withdrawing group in the para-substituted aromatic ring, enabling a $\pi$-stacking interaction between this aromatic ring and the tryptophan TRP185 electron-rich aromatic ring (Figure 5).

The presence of bromine in compound $\mathbf{4 e}$, which has a lower electronegativity and a larger atomic radius than the fluorine atom, did not allow a $\pi$-stacking interaction in the active site as with compound $\mathbf{4 h}$ and led to a similar activity of this compound for both the active site and the site of interaction 1 . It resulted in inhibitory activity at a concentration of $10 \mu \mathrm{mol} \mathrm{\textrm {L } ^ { - 1 }}$ and activating activity at a concentration of $100 \mu \mathrm{mol} \mathrm{L}^{-1}$ in the in vitro assay.

The hydrogen bonding interaction between the oxygen of the morpholine ring of compound $\mathbf{4 b}$ and the amide group of the amino acid asparagine ASN183, belonging to the catalytic triad of the rCPB 2.8 enzyme, may be essential for the inhibitory activity that this compound showed in the in vitro studies. Other factors that are not predicted by the molecular docking studies may have contributed to the higher inhibitory activity of compound $\mathbf{4 b}$, such as the interaction of nitrogen with positive formal charge of the nitro group with the highly flexible amino acid glutamate (GLU205), capable of being in or out of the S2 subsite, when favorable. Another factor that is not predicted by molecular docking studies is the formation of covalent bonds that may occur between the enzyme and the inhibitor compound.

Figure 6 shows the surface of the enzyme rCPB 2.8 bound to compound $\mathbf{4 b}$, demonstrating the active site to which the molecule is anchored, consisting mostly of negative surface potential in the region of interaction with the ligand, allowing interaction with positive or electrondeficient groups.

Activation and enhancement of the in vitro proteolytic activity of rCPB 2.8 enzyme that is produced by some compounds may be related to the preference of these compounds in binding to other sites of interaction of this enzyme, known as allosteric sites.

Three possible sites of interaction with micromolecules were found. Among the studied pockets, one had an interaction profile similar to the one obtained from the in vitro studies that resulted in an increased $\mathrm{rCPB} 2.8$ proteolytic activity, titled as "site of interaction 1". Increasing the binding affinity of a compound at the site 


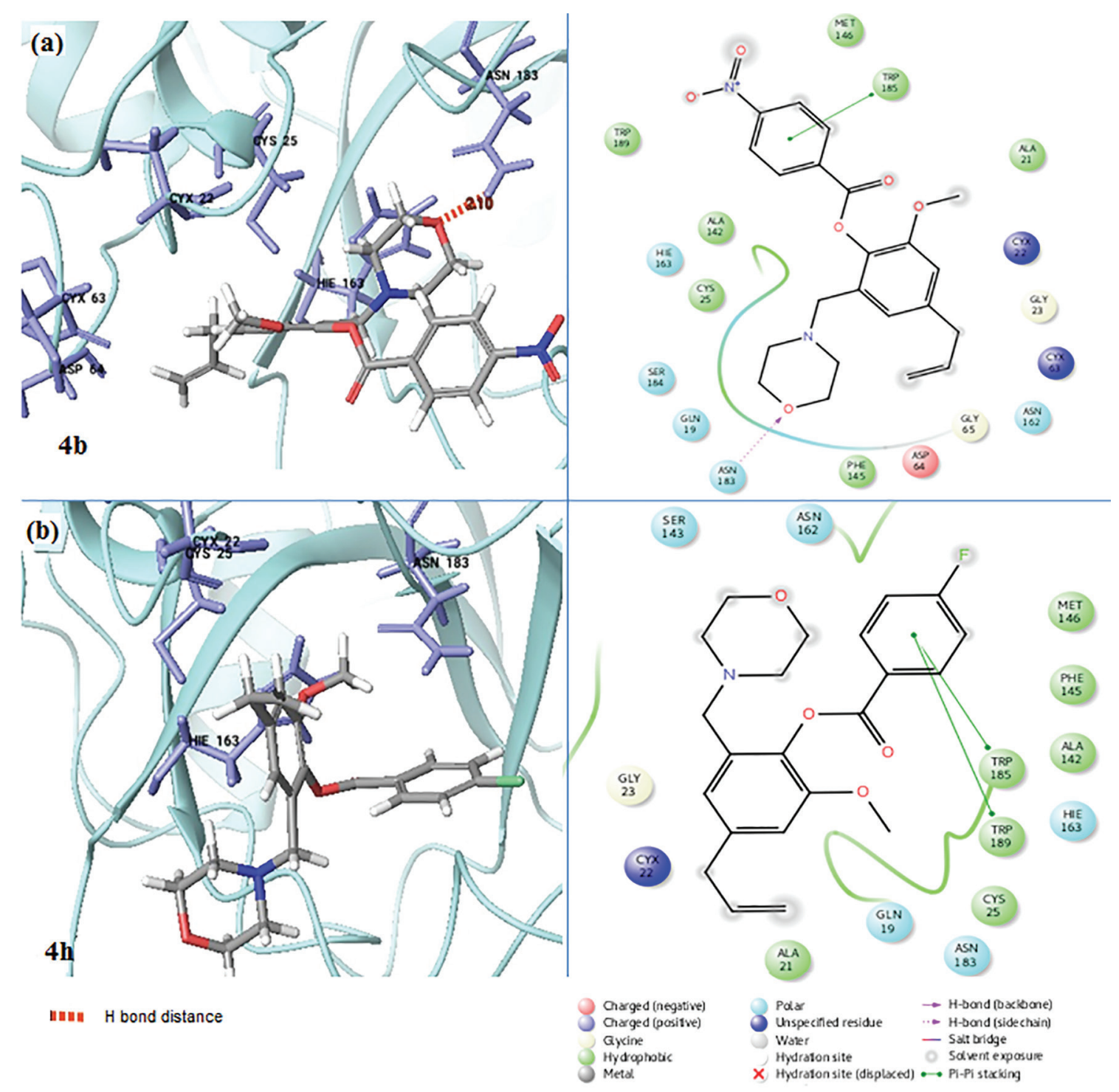

Figure 5. 3D structure representing the hydrogen bond between protein and ligand (orange dotted line), as well as the distance between the atoms that participate in this interaction, and 2D scheme demonstrating interactions between residues of the enzyme and the compounds (a) $4 \mathbf{b}$ and (b) $4 \mathbf{h}$.

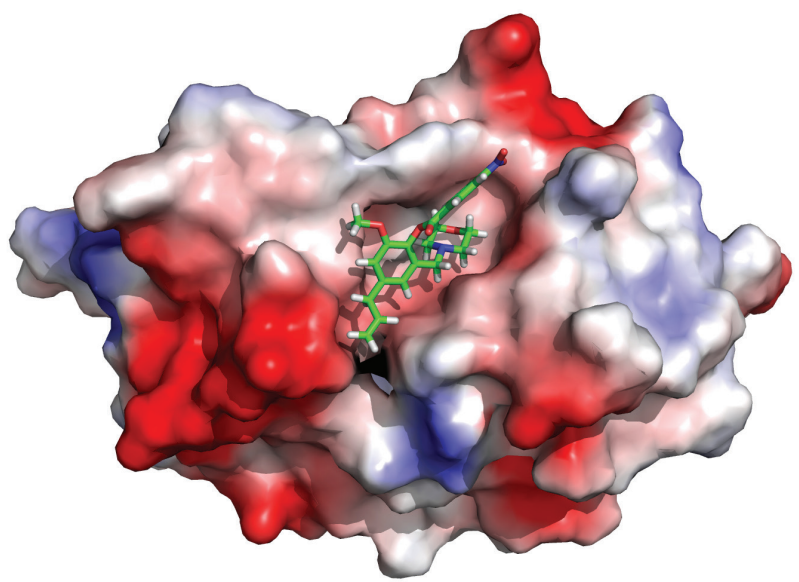

Figure 6. Electrostatic surface potential of the enzyme rCPB 2.8 bound to compound $\mathbf{4 b}$ (scale from -70.232 (negative, red) to 70.232 (positive, blue)). of interaction 1 would result in a lower glide score and an increase in enzyme activity as a result of a change in the conformation of the enzyme exerted by the allosteric site. The glide score and the enzymatic activity profiles of each interaction site are shown in Figure 7.

The interaction site 1 is located in the lysine residue LYS159 region, close to the active site. The possible sites of interaction with micromolecules are highlighted in green and the interaction site 1 is highlighted in dark green anchored with compound $\mathbf{4 c}$ in Figure 8.

According to the glide score values, the compounds that had the greatest interaction with the allosteric site (site of interaction 1) were the compounds $\mathbf{2}, \mathbf{4} \mathbf{c}$ and $\mathbf{4 f}$. These compounds exerted the highest activating rates of this enzyme in both in vitro and in silico studies. 

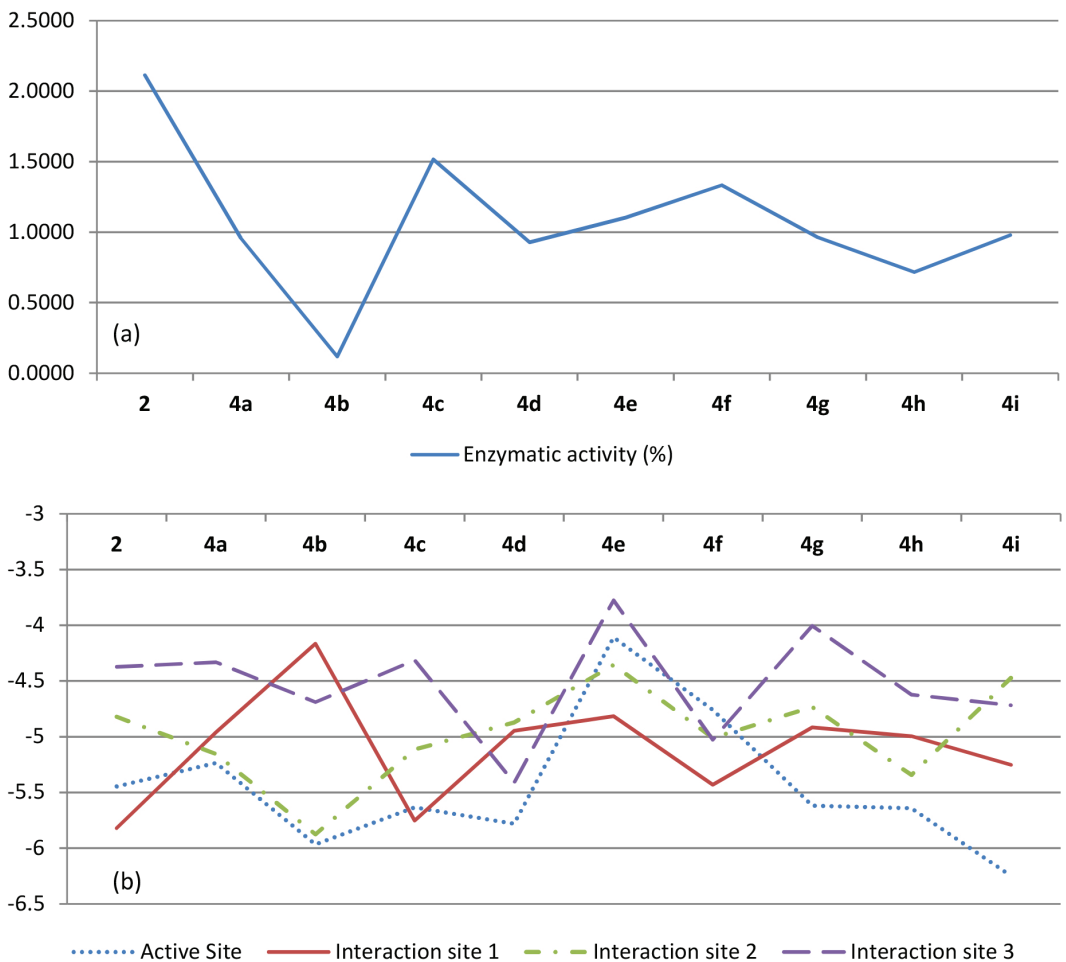

Figure 7. The glide score (a) and the enzymatic activity profiles of each interaction sites (b).
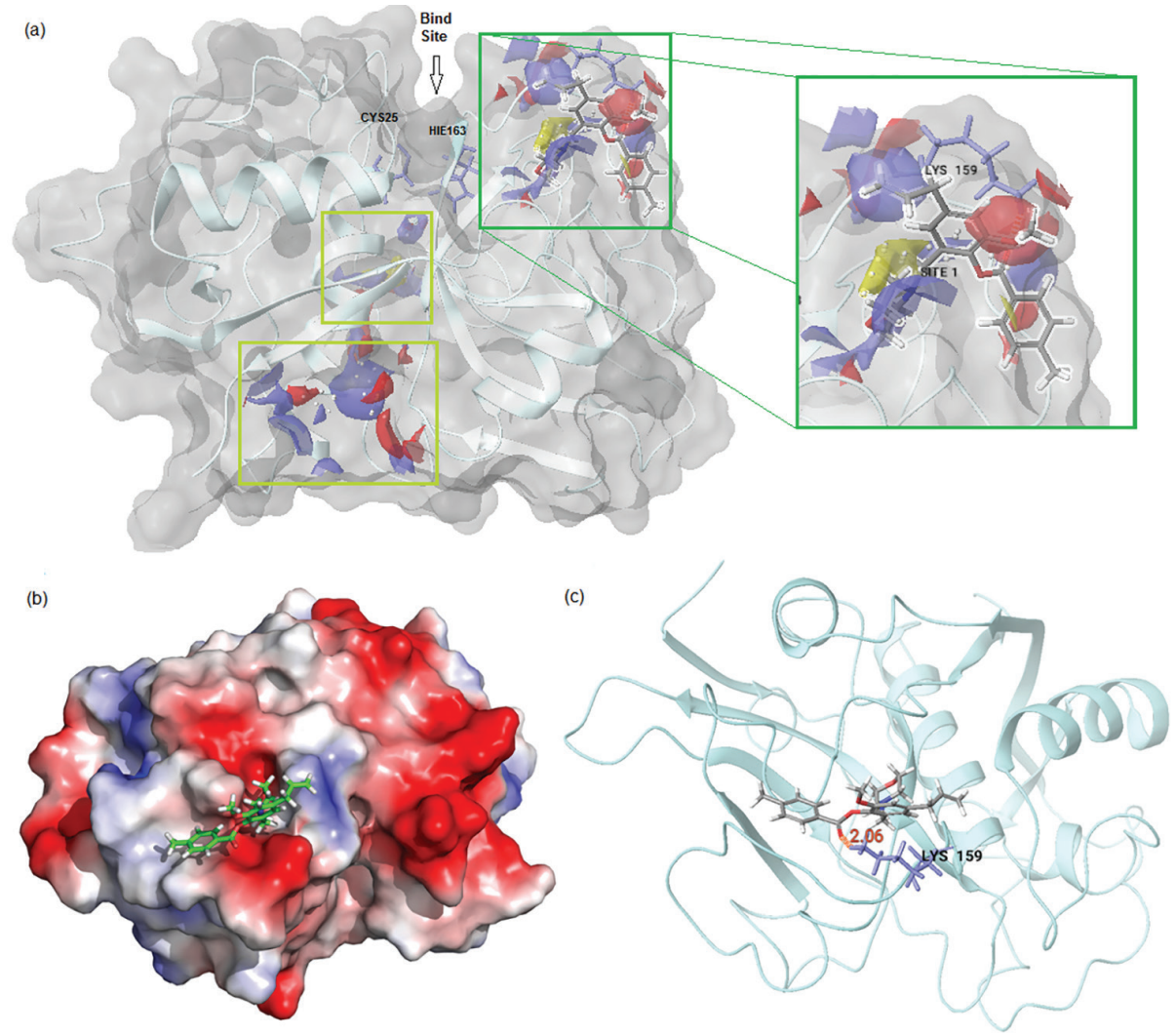

Figure 8. Interaction profile between compound $\mathbf{4 c}$ and the "interaction site 1" of rCPB 2.8. (a) The surface of the rCPB 2.8 enzyme with the active site and the 3 sites of interaction predicted by the SiteMap program (Schrödinger) highlighted in green, with the site with the best interaction profile linked to $\mathbf{4 c}$ compound; (b) electrostatic surface potential of the enzyme containing the ligand $\mathbf{4 c}$ at the allosteric site (scale -70.232 (negative, red) to 70.232 (positive, blue)); (c) ligand $\mathbf{4 c}$ forming a hydrogen bond with the residue LYS159 at the allosteric site. 
Considering the analysis of the interaction profile in the studied allosteric site, it is possible to verify its higher affinity for smaller and higher lipophilic molecules. The $\log \mathrm{P}$ calculated using the QikProp ${ }^{46}$ program, for molecules $\mathbf{4 c}, \mathbf{4 e}$ and $\mathbf{4 f}$ were $3.609,3.867$ and 4.292, respectively, characterizing them as the most lipophilic and non-bulky molecules in the series.

\section{Conclusions}

In summary, a series of novel eugenol esters were synthesized, their activity against rCPB 2.8 enzyme was tested, and the enzyme activity of the compounds was compared using a molecular modeling study. In the study of inhibition of rCPB 2.8 enzyme activity, only the compound $\mathbf{4 b}$ showed considerable activity at a concentration of $100 \mu \mathrm{mol} \mathrm{L}^{-1}$, reducing the activity of this enzyme by $88 \%$. The possible interaction of the rCPB 2.8 enzyme with positively charged groups has already been reported to be a result of the presence of a flexible amino acid glutamate $(\mathrm{GLU} 205)^{8}$ and may be responsible for the affinity between compound $\mathbf{4 b}$, which contains a positively charged nitrogen in the nitro group. Compounds $\mathbf{4 a}, \mathbf{4 d}$, 4g, $\mathbf{4 h}$ and $\mathbf{4 i}$ showed low inhibitory activity, with 4.3, 7.2, $3.8,28.3$ and $2.2 \%$ inhibition rates, respectively, with the rCPB 2.8 enzyme, also at a concentration of $100 \mu \mathrm{mol} \mathrm{L}^{-1}$.

The in vitro activation of the enzyme rCPB 2.8 by compounds $2, \mathbf{4 c}, \mathbf{4 e}$ and $\mathbf{4 f}$ may be related to the interaction of these compounds with an allosteric site, which would lead to a conformational change in the active site increasing its interaction with the substrate. Among the pockets studied, one showed an interaction profile similar to that obtained in the in vitro studies that resulted in an increase in the proteolytic activity of the enzyme rCPB 2.8. This cavity is located in the region of the LYS159 lysine residue, close to the active site, and shows greater affinity for smaller molecules with higher lipophilicity.

Results of in silico studies on affinity between the sites of interaction, the active site and the compounds, in terms of binding energy (glide score), are in accordance with the activation and inhibition activity profiles obtained from in vitro biological studies of the enzyme $\mathrm{rCPB} 2.8$, and it is possible to suppose a correlation between the allosteric site located in the region of the LYS159 lysine residue and the verified enzymatic activation.

\section{Supplementary Information}

Supplementary data associated with this article are available free of charge at http://jbcs.org.br as a PDF file.

\section{Acknowledgments}

The authors would like to thank CAPES, FAPEMIG (APQ-01641-12), Rede Mineira de Química (RQ-MG) supported by FAPEMIG (CEX, RED-00010-14), FAPESP (2016/25112-4 WASJ), INCT-INOFAR (grant CNPq 573.564/2008-6), FINEP and CNPQ for providing financial support for this research project.

\section{References}

1. Frade, A. F.; Oliveira, L. C.; Costa, D. L.; Costa, C. H.; Aquino, D.; Van Weyenbergh, J.; Barral-Netto, M.; Barral, A.; Kalil, J.; Goldberg, A. C.; Infect., Genet. Evol. 2011, 11, 912.

2. Van Griensven, J.; Carrillo, E.; López-Vélez, R.; Lynen, L.; Moreno, J.; Clin. Microbiol. Infect. 2014, 20, 286.

3. http://www.who.int/mediacentre/factsheets/fs375/en/, accessed in May 2017.

4. Azizi, H.; Hassani, K.; Taslimi, Y.; Najafabadi, H. S.; Papadopoulou, B.; Rafati, S.; Parasitology 2009, 136, 723.

5. Judice, W. A. S.; Manfredi, M. A.; Souza, G. P.; Sansevero, T. M.; Almeida, P. C.; Shida, C. S.; Gesteira, T. F.; Juliano, L.; Westrop, G. D.; Sanderson, S. J.; Coombs, G. H.; Tersariol, I. L. S.; PLoS One 2013, 8, 1.

6. Mottram, J. C.; Frame, M. J.; Brooks, D. R.; Tetley, L.; Hutchison, J. E.; Souza, A. E.; Coombs, G. H.; J. Biol. Chem. 1997, 272, 14285.

7. Siklos, M.; BenAissa, M.; Thatcher, G. R.; Acta Pharm. Sin. B 2015, 5, 506.

8. Gillmor, S. A.; Craik, C. S.; Fletterick, R. J.; Protein Sci. 1997, $6,1603$.

9. St. Hilaire, P. M.; Alves, L. C.; Sanderson, S. J.; Mottram, J. C.; Juliano, M. A.; Juliano, L.; Coombs, G. H.; Meldal, M.; ChemBioChem 2000, 1, 115.

10. Turk, V.; Stoka, V.; Vasiljeva, O.; Renko, M.; Sun, T.; Turk, B.; Turk, D.; Biochim. Biophys. Acta 2012, 1824, 68.

11. Groves, M. R.; Taylor, M. A.; Scott, M.; Cummings, N. J.; Pickersgill, R. W.; Jenkins, J. A.; Structure 1996, 4, 1193.

12. Modjinou, T.; Versace, D. L.; Abbad-Andallousi, S.; Bousserrhine, N.; Dubot, P.; Langlois, V.; Renard, E.; React. Funct. Polym. 2016, 101, 47.

13. Pereira, F. O.; Mendes, J. M.; Lima, E. O.; Med. Mycol. 2013, $51,507$.

14. Islamuddin, M.; Sahal, D.; Afrin, F.; J. Med. Microbiol. 2014, 63,74 .

15. ht tp://www.rcsb.org/pdb/explore/explore. do?structureId=1EWP, accessed in September 2017.

16. Abrão, P. H.; Pizi, R. B.; de Souza, T. B.; Silva, N. C.; Fregnan, A. M.; Silva, F. N.; Coelho, L. F.; Malaquias, L. C.; Dias, A. L.; Dias, D. F.; Veloso, M. P.; Carvalho, D. T.; Chem. Biol. Drug Des. 2015, 86, 259. 
17. Zhang, C. Y.; Liu, X. H.; Wang, B. L.; Wang, S. H.; Li, Z. M.; Chem. Biol. Drug Des. 2010, 75, 489.

18. Gamble, A. B.; Garner, J.; Gordon, C. P.; O’Conner, S. M. J.; Keller, P. A.; Synth. Commun. 2007, 37, 2777.

19. Bellamy, F. D.; Ou, K.; Tetrahedron Lett. 1984, 25, 839.

20. Leatherbarrow, R. J.; GraFit Version 5.0, Erithacus Software, Horley-Surry, United Kingdom, 2001.

21. Gontijo, V. S.; Judice, W. A.; Codonho, B.; Pereira, I. O.; Assis, D. M.; Januário, J. P.; Caroselli, E. E.; Juliano, M. A.; Dosatti, A. C.; Marques, M. J.; Viegas Junior, C.; dos Santos, M. H.; Eur. J. Med. Chem. 2012, 58, 613.

22. Altschul, S. F.; Madden, T. L.; Schäffer, A. A.; Zhang, J.; Zhang, Z.; Miller, W.; Lipman, D. J.; Nucleic Acids Res. 1997, 25, 3389.

23. Lovell, S. C.; Davis, I. W.; Arendall, W. B.; de Bakker, P. I.; Word, J. M.; Prisant, M. G.; Richardson, J. S.; Richardson, D. C.; Proteins 2002, 50, 437.

24. Sievers, F.; Wilm, A.; Dineen, D.; Gibson, T. J.; Karplus, K.; Li, W.; Lopez, R.; McWilliam, H.; Remmert, M.; Söding, J.; Thompson, J. D.; Higgins, D. G.; Mol. Syst. Biol. 2011, 7, ID 539.

25. Šali, A.; Blundell, T. L.; J. Mol. Biol. 1993, 234, 779.

26. Laskowski, R. A.; MacArthur, M. W.; Moss, D. S.; Thornton, J. M.; J. Appl. Crystallogr. 1993, 26, 283.

27. Hess, B.; Kutzner, C.; Van der Spoel, D.; Lindahl, E.; J. Chem. Theory Comput. 2008, 4, 435.

29. Van der Spoel, D.; Hess, B.; Wiley Interdiscip. Rev.: Comput. Mol. Sci. 2011, 1, 710.

29. Hornak, V.; Abel, R.; Okur, A.; Strockbine, B.; Roitberg, A.; Simmerling, C.; Proteins: Struct., Funct., Bioinf. 2006, 65, 712.

30. Gordon, J. C.; Myers, J. B.; Folta, T.; Shoja, V.; Heath, L. S.; Onufriev, A.; Nucleic Acids Res. 2005, 33, W368.

31. Bussi, G.; Donadio, D.; Parrinello, M.; J. Chem. Phys. 2007, 126, ID 014101.

32. Parrinello, M.; Rahman, A.; J. Appl. Phys. 1981, 52, 7182.
33. Hess, B.; Bekker, H.; Berendsen, H. J. C.; Fraaije, J. G. E. M.; J. Comput. Chem. 1997, 18, 1463.

34. Essmann, U.; Perera, L.; Berkowitz, M. L.; Darden, T.; Lee, H.; Pedersen, L. G.; J. Chem. Phys. 1995, 103, 8577.

35. Schrödinger; Schrödinger Release 2015-2: SiteMap, Schrödinger, LLC, New York, NY, 2015.

36. Schrödinger; Schrödinger Release 2015-2: LigPrep, version 3.4, Schrödinger, LLC, New York, NY, 2015.

37. Schrödinger; Schrödinger Release 2015-2: Schrödinger Suite 2015-2 Protein Preparation Wizard, Epik version 3.2, Schrödinger, LLC, New York, NY, 2015; Impact version 6.7, Schrödinger, LLC, New York, NY, 2015; Prime version 4.0, Schrödinger, LLC, New York, NY, 2015.

38. Schrödinger; Small-Molecule Drug Discovery Suite 2015-2: Schrödinger Suite 2015-2 Induced Fit Docking Protocol, Glide version 6.7, Schrödinger, LLC, New York, NY, 2015; Prime version 4.0, Schrödinger, LLC, New York, NY, 2015.

39. Schrödinger; Schrödinger Release 2015-2, Maestro version 10.2.010, Schrödinger, LLC, New York, NY, 2015.

40. Schrödinger; The PyMOL Molecular Graphics System, version 1.74, Schrödinger, LLC, New York, NY, 2015.

41. Smith, M.; March, J.; Advanced Organic Chemistry: Reactions, Mechanisms, and Structure, Part 2, $6^{\text {th }}$ ed.; Wiley: New Jersey, USA, 2007.

42. Bowie, J. U.; Lüthy, R.; Eisenberg, D.; Science 1991, 253, 164. 43. Lüthy, R.; Bowie, J. U.; Eisenberg, D.; Nature 1992, 356, 83.

44. Kabsch, W.; Sander, C.; Biopolymers 1983, 22, 2577.

45. Kenakin, T. P.; A Pharmacology Primer: Techniques for More Effective and Strategic Drug Discovery, $6^{\text {th }}$ ed.; Elsevier: Oxford, UK, 2014.

46. Schrödinger; Schrödinger Release 2015-2: QikProp, Schrödinger, LLC, New York, NY, 2015.

Submitted: August 1, 2017

Published online: October 25, 2017 